\title{
(息)
}

Citation:

Fletcher, T (2015) Cricket, migration and diasporic communities. Identities, 22 (2). 141 - 153. ISSN 1070-289X DOI: https://doi.org/10.1080/1070289X.2014.901222

Link to Leeds Beckett Repository record:

https://eprints.leedsbeckett.ac.uk/id/eprint/140/

Document Version:

Article (Accepted Version)

The aim of the Leeds Beckett Repository is to provide open access to our research, as required by funder policies and permitted by publishers and copyright law.

The Leeds Beckett repository holds a wide range of publications, each of which has been checked for copyright and the relevant embargo period has been applied by the Research Services team.

We operate on a standard take-down policy. If you are the author or publisher of an output and you would like it removed from the repository, please contact us and we will investigate on a case-by-case basis.

Each thesis in the repository has been cleared where necessary by the author for third party copyright. If you would like a thesis to be removed from the repository or believe there is an issue with copyright, please contact us on openaccess@leedsbeckett.ac.uk and we will investigate on a case-by-case basis. 
Cricket, migration and diasporic communities

Thomas Fletcher, Leeds Metropolitan University, UK

\begin{abstract}
Ever since different communities began processes of global migration, sport has been an integral feature in how we conceptualise and experience the notion of being part of a diaspora (Burdsey et al. 2013). Sport provides diasporic communities with a powerful means for creating transnational ties, but also shapes ideas of their ethnic and racial identities. In spite of this, theories of diaspora have been applied sparingly to sporting discourses. Due mainly to its central role in spreading dominant white racial narratives within the British Empire, and the various ways different ethnic groups have 'played' with the meanings and associations of the sport in the (post-)colonial period, cricket is an interesting focus for academic research. Despite W.G. Grace's claim that cricket advances civilisation by promoting a common bond, binding together peoples of vastly different backgrounds, to this day cricket operates strict symbolic boundaries; defining those who do, and equally, do not belong. C.L.R. James' now famous metaphor of looking 'beyond the boundary' captures the belief that, to fully understand the significance of cricket, and the sport's roles in changing and shaping society, one must consider the wider social and political contexts within which the game is played. The collection of papers in this special issue does just that. Cricket acts as the point of departure in each, but the way in which ideas of power, representation and inequality are 'played out' is unique in each.
\end{abstract}

Key words: Colonial, Cricket, Diaspora, Empire, Englishness, Migration

\title{
Introduction
}

Members of migrant and diasporic communities have made a significant contribution to the sport of cricket. The process of, and politics behind, migration was fundamental to understanding cricket cultures during times of the British Empire. According to Malcolm (2013) it is England's colonial history which is the key to explaining the diffusion of cricket around the world, and thus the relationship between cricket and contemporary diasporic identities. The British Empire provided the context and much of the momentum for the diffusion of the game through the English-speaking world when British migrants introduced the game to 'indigenous' communities in the colonies (Khondker 2010). This relationship was defined by a number of processes; but namely the 'Anglicisation' of local elites, and symbolic competition and subaltern resistance from below. The history of colonialism, which entailed forced migration, economic exploitation, political subjugation and cultural domination also led to important cross-cultural transactions (ibid.); the result of which continue to this day within the cultural memories and experiences of diasporic communities around the world. Indeed, it is frequently cited that diasporic communities have developed a particular fondness for the game precisely because it allowed them to engage in anti-colonial struggle(s) against England. In so doing they help to shed light on the problematic relationships between power, colonialism and, in many cases, the experience of being colonised.

Such struggles over power and representation were at the heart of what C.L.R. James 2005[1963], ix) was referring to when he asked: 'what do they know of cricket who only cricket they know?' In asking this 
question James was encouraging us (as academics, activists and enthusiasts of the game) to think critically about the wider context(s) of the sport - to not think of it simply as sport, where runs are scored, wickets are taken, winners and losers created - rather to think of cricket (and we may also add other sports) as having the power to articulate the complexities of social identities in the contemporary world in which they are played. Inevitably, the contexts in which cricket is played, watched and consumed are temporally and spatially contingent. James for example, was writing specifically about the English-speaking Caribbean during the middle of the twentieth century. For Carrington and Andrews $(2013,8)$, at this time, 'cricket was unavoidably connected to the politics of the age, namely the Caribbean anticolonial struggle against British racism and domination'. James' famous metaphor of looking 'beyond the boundary' captures his belief that, to fully understand the significance of cricket, and the sport's roles in changing and shaping society, one must consider the wider social and political contexts within which the game is played (ibid.). The collection of papers in this special issue does just that. Cricket acts as the point of departure in each, but the way in which ideas of power, representation and inequality are 'played out' are inevitably specific to each context.

\section{Migrant and diasporic communities}

The 'immigration question' entered public consciousness with growing regularity in the post-Second World War period. In Britain and elsewhere, post-war migration from the Caribbean, Asia sub-continent and Africa was driven mainly by economic imperatives. Due to their phenotypical appearance post-war migrants were 'racially' marked. This 'racialisation' restricted their access to cultural resources and spaces taken for granted by white people, and made them vulnerable to racial prejudice and institutionalised racism (Stephenson 2006). Consequently, the majority of migrants, regardless of their background or level of education pre-migration, were initially employed in low-paid manual occupations. A consequence of this was that migrant groups would tend to gravitate to certain (cheaper) areas of towns and cities, meaning that these areas quickly became enclaves, associated with these groups, and subsequently racialised. According to Stephenson (2006, 286) 'the racialisation of space and territory is a notable irritant to the establishment of commonality; restricting minorities from appreciating other cultures and societies.'

Explanations for the movement of people around the world are varied and complex. According to Modood and Salt (2012), historically, there have been different streams of movement - some with similar, some with different rationales. They argue that migrants from particular origins have tended to arrive in waves, creating new diaporas, chains and networks in the process. International migration cannot be explained via a homogenous framework however. Whilst migrants from specific origins will inevitably share some characteristics and experiences, migration is experienced individually. Not least, we must consider the context(s) of migration, the individual's expectations of what their life will be like post-migration, the migrant's expected length of stay, and their experiences, and their family's experiences, post-migration. With reference to the latter there is a growing appreciation of the need to consider the centrality of popular cultural forms, including sport, in the lives of migrant communities. 
In saying this, the terms 'migrant' and 'migration' arguably do not possess the level of analytic strength they once did. Over the last two-three decades the terms 'diaspora' and 'transnational' have gained greater cogency instead. Dominic Malcolm (2013) identifies four reasons why the term diaspora in particular has come to be preferred over those of migrant and migration. Firstly, many of the people whom are now described as diasporic are not actually migrants, but the offspring of those who have previously experienced migration. Secondly, the term migrant is nation-centric, where nation and society are unproblematically equated, with analysis being confined to the latter. Thirdly, the term migrant - when used as a euphemism for describing those 'not from this place' - marginalises, racialises and 'Others' entire communities. Finally, migration suggests a once-off event - an act of dis-/re-location - and a one-way process whereby 'old' affiliations and identifications with a 'homeland' are severed and automatically replaced by new affiliations and identifications with the settling place when, in fact, 'In contemporary societies migrations are more commonly multiple and multi-directional' (ibid., 107).

As the idea of diaspora developed, contestations over its meanings and significance also emerged. Diaspora has conventionally referred to the transnational dispersal of a cultural community. Raman $(2003,20)$ suggests that early readings of diaspora made a number of assumptions; namely that they were born of suffering and loss, contained a desire to return to a "homeland" ... [and were] potentially radical in character, a subaltern in the midst of dominant political structures.' Raman argues that these assumptions prioritise the legitimacy of those communities who were forced to leave a dwelling place, e.g. asylum seekers. As a result, they are unable to account for migrant communities who are in control of their movements (see Stephenson 2006). Raman rightly observes that early conceptualisations of diaspora were largely essentialist. Subsequent iterations (developed primarily from the work of the late Stuart Hall (1994) and Paul Gilroy (1993)) are increasingly nuanced and anti-essentialist - instead interpreting diaspora 'as a subversive mode of identification, which challenged notions of absolute states of being' (Raman 2003).

Of these more contemporary interpretations, Anthias (2001) conceives of diaspora as a particular type of ethnic category that exists across the boundaries of nation states rather than within them. Kalra et al. (2005) argue similarly that diaspora means to be from one place, but of another. Thus, understanding diaspora necessitates we understand 'migrant' communities as existentially connected to a specific place of origin or an imagined body of people, which extend beyond the current dwelling place. In saying this some conceptualisations of diaspora have been criticised for reinforcing primordial, or absolutist notions of 'origin' and 'true-belonging' (Anthias 2001, 632). However, belonging to a diaspora is not necessarily about identification with a single source of cultural heritage. Rather, diaspora should be conceptualised as a state of consciousness, which is not necessarily linked with a sense of rootedness and/or belonging (Brah, 1996; Anthias, 2001).

Central to all diasporas are the internal differences (gender, class, age, political affiliations etc.) that exist within. Indeed, according to Brah $(1996,183)$, a diaspora is a heterogeneous collective of different narratives, as the journeys undertaken by members of a diaspora and their experiences in their host society are subjective, 'each with its own history and particularities'. The notion of 'history' is central to understanding 
diaspora. According to Raman (2003) the process of migration does not necessarily result in diasporic identification. She cautions that:

Diasporic consciousness is, rather, created at certain moments in time because of a confluence of circumstances. A diaspora is characterised by the historical contingency of its 'moment', and tends to manifest itself at times of 'need'...it is not so much what diaspora 'is', but rather, what diaspora 'does' that is of interest. (ibid.)

Consequently, belonging is never a question of affiliation to a singular idea of ethnicity or nationalism, but rather about the multivocality of belongings (Kalra et al. 2005, 29). This multivocality however, can be both enabling and constraining, in that, if we think about diasporas as possessing very fluid notions of 'rootedness', we should note that this may also translate into a shared sense of (non)belonging. Within the discourse of diaspora there is an emphasis upon the place of origin and, for many, this is central to the construction of identity and solidarity within, as the collective memory and idealisation of the 'homeland' becomes an important way to connect with 'home' and identify within the wider diaspora (Harkin In Press). Thus, as I have argued elsewhere, 'diasporic identities do not simply revolve around either, the reproduction of existing cultures within new settings; or the appropriation of new ones. Instead, diasporic identities must [though I would now amend to 'may usefully'] be viewed as being fluid, syncretic and hybrid' (Fletcher 2012, 617). As the late Stuart Hall wrote:

The diaspora experience...is defined, not be essence or purity, but by the recognition of a necessary heterogeneity and diversity; by a conception of 'identity' which lives with and through, not despite, difference; by hybridity. Diaspora identities are those which are constantly producing and reproducing themselves anew, through transformation and difference. (Hall 1994, 235)

\section{The analytical potential of cricket}

Ever since different communities began processes of global migration, sport has been an integral feature in how we conceptualise and experience the notion of being part of a diaspora (Burdsey et al. 2013). Over time, diasporic communities have established numerous ways of maintaining links with 'home' even as they put down new roots. One conduit through which the interplay between old and new homes was reproduced was through the love of sport many brought with them (Raman, this volume; Fletcher and Spracklen, 2013). For many migrants, sport features prominently in how they imagine their new 'homes' to be. Burdsey et al. (2013) argue that sport provides diasporic communities with a powerful means for creating transnational ties, but also shapes ideas of their ethnic and racial identities. Amongst other things sport can provide important coping mechanisms from the experience of being dislocated, but it can also afford opportunities for political mobilisation/resistance and strategies of adaptation to an unknown (and often, hostile) social environment. 
According to Burdsey et al (2013: 211) 'sport becomes a realm of symbolic attachment by diasporic communities that betrays a whimsical, passing affiliation with sport; rather sport is a significant medium through which local experiences are translated, diasporic parameters reconfigured and national identity(ies) complicated'. They go on to say that sport can also provide important activities, spaces and relationships, and forms of social capital for migrant and diasporic communities, enabling them to identify with, and celebrate, spaces nominally representing 'nation', 'home' and 'homeland'. In spite of this, Joseph (2012, 5) notes that diaspora theory has been used sparingly to examine and exemplify sport-related social forms, group consciousness, and transnational cultural forms.' She identifies cricket as one exception to the rule where a number of studies focusing on African Caribbean and South Asian diasporas do exist.

In arguing for the importance of cricket in articulating the complexity of contemporary social identities, I do not wish to enter a broader debate about the legitimacy of sport as an analytical tool for articulating social problems. A number of scholars have already made a strong case for sport in this respect. For example, in 2012, this journal's associate, Ethnic and Racial Studies, published its first ever volume devoted to sport. In the editorial, Ben Carrington (2012, 965-966) states that, over the last decade social scientific studies on race and sport have developed with much greater regularity. He cites the growing number of journal special issues devoted to sport as indicative of the bourgeoning acceptance of sport within 'mainstream' studies of race and racism. However, he cautions that even now, 'it is still the case that otherwise comprehensive and authoritative introductions, readers, and edited volumes on race and racism can still be written with barely a mention of sport as a key aspect of popular culture, despite the fact that sport is often an important (and occasionally vital) site for racial contestations and meanings in its own right.' It remains the case then that sport is, for some at least, of marginal importance within these debates (see Carrington 2013 for further discussion). As C.L.R. James noted:

A professor of political science publically bewailed that a man of my known political interests should believe cricket had ethical and social values. I had no wish to answer. I was just sorry for the guy. (James 2005[1963], 241).

Gemmell (2007) argues that sport is a direct reflection of the society it evolves out of. Consequently, cricket is reflective of particularly British (or English) traits and virtues; many of which have been maintained in the countries where cricket was exported to and is subsequently played, and which are maintained through different diasporas. Due mainly to its central role in spreading dominant white racial narratives within the British Empire, and the various ways different ethnic groups have 'played' with the meanings and associations of the sport in the (post-)colonial periods, cricket is an interesting case study for academic research. Before moving on to these discussions, an issue with terminology needs to be addressed.

The literature on cricket and its relationship with the British Empire has a tendency to conflate the terms English and 'Englishness' with British and 'Britishness'. This tendency to conflate these terms is not specific to cricket and/or sport writings however (see McCrone 2002). As the forthcoming discussion will illustrate cricket is widely considered to having been central to the expansion of the British Empire. But this 
expansion, and the role of cricket in this, was largely commanded by the English, as opposed to Britain as a national collective. Therefore, 'to fully account for the relationship between cricket and colonization we must therefore also consider the process of "internal colonization" (Malcolm 2013, 51). Consequently, when in this paper I refer to cricket and Britain, the British, or the British Empire, a more accurate reading would be to think of England and the English, whilst also accounting for the nuances of the unequal distribution of power, and relative interest in cricket, between the 'home' nations within the Empire.

The ubiquity of cricket in English popular culture has made it synonymous with expressions of white 'Englishness' and, related to this, England's superior moral worth over other cricket playing nations (and their inhabitants). According to Williams $(2001,18)$ the British/English took the global reach and influence of the Empire as demonstrative of their own self-worth, and thus, it became 'intimately bound up with notions of white supremacy'. In addition, a number of authors have noted that the English take a great deal of pride from the fact that the sport is neither played, nor its nuances understood, in countries like America and France. Neville Cardus' $(1945,7)$ opening to English Cricket is indicative of this:

None except the people of England or of the English-speaking countries has excelled at cricket. Other nations not obsessed by sport are able to hold their own with us at tennis, golf, football, but cricket is incomprehensible to them, a possession or mystery of a clan, a tribal rite.

Having been created and codified in England cricket fast became one of England's most cherished institutions. Cardus asserts that, as an English cultural icon, cricket is more than a game; rather it signifies something overarching, religious, almost totemic (ibid.). The interdependency of British/English national identity and the imperial experience is well depicted in the comments of former MCC President Pelham Warner:

Cricket has become more than a game. It is an institution, a passion, one might say a religion. It has got into the blood of the nation, and wherever British men and women are gathered together there will the stumps be pitched. North, South, East and West, throughout the Empire, from Lord's to Sydney, from Hong Kong to the Spanish Main, cricket flourishes. (cited in Malcolm 2013, 49)

Warner quite clearly over-states the reach and influence of cricket, both within Britain and throughout the colonies. The very suggestion of cricket being the game par excellence uniting the British Empire serves only to obscure deeper complexities (Malcolm 2013). Malcolm argues that the idea of cricket as the 'imperial game' projects a false homogeneity upon the Empire; obscuring the fact that its diffusion was both uneven and heterogeneous. Cricket was not unproblematically accepted wherever the British attempted to export it. Moreover, even in those countries where cricket was exported and has subsequently been taken up as a national sport, the meanings attached to cricket have been creatively appropriated by different cultures, and 
have also become a defining feature of their (post-)colonial national identities (see Raman; Fletcher and Walle, this volume).

Cricket does not (and has never) offered equal opportunities to all who have watched, played or followed it. In fact, cricket has often been regarded as the archetypal elitist institution; run by 'toffs' for 'toffs'. More recently, this classed depiction of cricket's exclusivity has been extended to other axes of power; namely, race and ethnicity, gender and sexuality. Indeed, despite W.G. Grace's claim that cricket advances civilisation by promoting a common bond, binding together peoples of vastly different backgrounds (Sandiford $1998,22)$, to this day cricket operates strict symbolic boundaries; defining those who do, and equally, do not belong. According to Sandiford $(1998,1)$ the snobberies pertaining to class afflicting the sport in Victorian England have 'reappeared in the racial and ethnic divides bedevilling the sport almost wherever it was taken.'

Historically, cricket was the domain of the white English elite. Their agenda at the outset was to successfully export the laws of the game; first to the colonies and then the rest of the world. Hence, a set of English/British laws would accompany teams touring the colonies, and matches would be played with the desired etiquette and civilisation of the British (Williams 2001). Thus, cricket had an educative role within the Empire (Malcolm 2013); it represented a form of 'colonial tutelage' (Carrington 2010, 42; see also Hall 1996). Initially, the British considered cricket to be a means to a civilised world; promoting team work, obedience to the rules, and respect for 'fair play'. Disguised by utterances of social inclusion however, was a very specific agenda of cultural homogenisation via imperialism. Underlying these processes was the assumption that white populations were more advanced, civilised and rational than native populations within the colonies.

Carrington (2010 continues this idea by arguing how 'rationality' - an assumed cognitive function of white populations which was perceived to be both lacking and unobtainable by certain people - was used to construct and justify the 'very concept of the white, western, masculine self' and, in so doing, would help to explain 'why certain subjects, more often women, Native peoples and blacks, should be restricted from the public sphere and hence from citizenship due to their supposed inherent irrationality' (Carrington 2010, 41-42 original emphasis). This power imbalance is well expressed by Crabbe and Wagg $(2005,210)$ :

In the racialised culture of this empire, white settlers ruled indigenous 'coloured' populations, and part of the pretext for this political arrangement was the supposedly greater rationality of white people, against the sensuality, lack of emotional restraint or intelligence of the 'native'. In what Gilroy terms 'the historic folk grammar of British racism', animal blacks enjoy an excess of brute physicality and wily oriental gentlemen conversely display a surfeit of cerebral power, while only the Anglo-Brit is able to luxuriate in the perfect equilibrium of body and mind.

Crabbe and Wagg rightly continue by arguing that the importance of these conceptualisations is not in their legitimacy, but the Anglocentric determination of acceptable 'sporting' attributes and, perhaps more importantly, their presence within a framework defined along the lines of 'race' and nation.

According to Malcolm $(2013,55)$, the British framed colonisation 'as a moral obligation to bring their particular form of civilization to those they were conquering.' This was believed to be possible due to an 
'ethnocentric imperialist hierarchy' which existed in English cricket (Crabbe and Wagg, 2005). This hierarchy is realised in the way that when English teams toured the colonies they would often replicate forms of the game already being played 'at home', rather than adapting the game's customs to better reflect those of local cultures (Guha, 2002). Consequently, it is argued that cricket exhibits what Delgado (2008) calls 'locked-in racism'; that is, once in place, it is effortlessly maintained through numerous everyday mechanisms, rules and habits.

Subordinated groups are not passive victims to their domination. In fact some use sport to challenge the existing social order. C.L.R. James (2005[1963]) noted how cricket - due to its position both as the cultural embodiment of the values and mores of 'Englishness' and its 'missionary' role within British imperialism and colonialism - occupied a central site in many of the anti-colonial struggles between coloniser and colonised. Sport (and cricket) therefore, must be considered, not only as sites where domination can be imposed, but also contested, redefined and transformed. Research should acknowledge the capacity for minority cultures to resist these ethnocentric discourses through, amongst other things, imposing (and exerting) their own ethnic identities on and through the game: what Appadurai $(1996,110)$ referred to as a 'simulacrum of warfare'. Indeed, Malcolm et al $(2010,232)$ assert how, 'If cricket in the nineteenth century was inextricably tied to British colonization and Imperial expansion...the development of the game in the twentieth century can perhaps best be described as a process of de-colonization and the national self-assertion of formerly subaltern peoples.' Malcolm (2013) later argued how one of the many paradoxes evident in the relationship between cricket and the British Empire's 'civilising' mission was that, by stressing the value and importance of masculinity and competitiveness in their practices, the British were effectively training the subaltern for resistance. Thus, for Malcolm, 'to fully account for the diffusion of cricket we need to consider elements of accident, education, indoctrination and acculturation' (ibid., 56). In addition to this, and as this special issue illustrates, we must also take care to account for the multiplicity of cricket itself in the narratives of different ethnic and diaspora groups.

\section{Structure of the Special Issue}

The collection opens with Simon Featherstone's paper 'Sport and the performative body in the early work of C.L.R. James'. Featherstone examines four of James' texts which are associated with his residence in Nelson, Lancashire, in Northern England, during 1932-33. The texts - fictional novel Minty Alley, 'political biography' The life of Captain Cipriani, Learie Constantine's autobiography Cricket and I, and the newspaper article 'The Greatest of All Bowlers' - 'make for an eclectic group even by James' standard'. Featherstone argues that these texts form a distinct group within James' overall literary canon. This is an important argument because previously, these texts have largely been thought to represent a 'preparatory phase' for James where he experimented with his ideas and refined his politics. Featherstone argues how, 'Whilst individual disciplines have celebrated one or other of them ... there has been little sense of their coherence as a distinctive rather than a formative phase of James' thinking'. In addition to examining their content Feathersone attempts to locate the significance of James' residence in Nelson where he wrote Cricket and I and 'The Greatest of All 
Bowlers'. Featherstone argues that James' stay in Nelson enabled him to establish and articulate 'an anticolonial politics rooted in both Caribbean and English performance cultures'.

Janelle Joseph's paper 'A narrative exploration of gender performances and gender relations in the Caribbean diaspora' also focuses on the performative body. Joseph centralises the voices of Caribbean women residing in Canada. She notes that the majority of research on Caribbean and Black diasporas has tended to focus on men's experiences, but tell us little about how women help shape masculinities and inform gender relations. The women in Joseph's paper are part of the cricket landscape in Canada, but they are not cricketers. They are instead the women in the lives of Caribbean Canadian men who do play the sport. Therefore, they are integral to our understanding of gender performances and gender relations within the diaspora. Joseph utilises a narrative approach where she created 'fictionalised narratives' of her observations and conversations. Joseph presents three narratives that identify the myriad ways that women are involved in identity making in the diaspora. She argues that women are linked to this predominantly male community through their nurturing, domestic, and sexualised gender performances, in that, they facilitate masculinity through supporting their husband/boyfriend's gender performances; (re)build relationships, kinship, community and a sense of being-at-home within the diaspora; and contribute to heterosexual masculine performances by being the objects of the male cricketer's affections.

Whereas Joseph notes that cricket provided the Caribbean diaspora in Canada a space to play out their diasporic consciousness, Matthew Stephen notes how in the late nineteenth and early twentieth centuries, cricket in Australia's Northern Territory was almost exclusively a white space, limiting participation amongst Aborigines and migrant communities. In his paper 'Cricket in the 'contact zone': Australia's colonial far north, 1869-1914' Stephen notes how, whilst in other parts of Australia cricket was considered to be a strong civilising tool in developing relationships between Aborigines and white communities, in the Northern territory, Aborigines were largely denied opportunities to participate. Stephen provides two detailed case studies of Northern Territory towns, Broome and Palmerstone, to articulate the relationship between cricket, white privilege and Aboriginal exclusion. While the white population was very much the minority in both towns, Stephen observes they were able to sustain their dominance via a number of processes underpinned by an ideology of 'control'. Stephen notes that there were exceptions to the rule; while racial segregation in sport was commonplace in both towns there were a few instances of Aborigine and migrant players crossing the 'colour line' to participate in cricket. However, he cautions that, in the main, the practice of cricket in the Northern Territory largely reinforced colonial narratives of white domination and, in the process, helped sustain an imagined community of white Britishness.

Megan Ponsford's contribution 'Breaking down racial barriers? The Maharaja or Patiala's 1935 Australian cricket tour of India' also provides an Australian case study. However, her focus is on a little known tour of India undertaken by an 'unofficial' Australia team. She argues that very little has previously been written about this tour because firstly, it was not sanctioned and secondly, its impacts were largely inconsequential on the game's overall development. In spite of this, she argues that the tour provides a 'uniquely Australian perspective on Oriental identity(ies) fuelled somewhat by a mounting criticism of British imperialism'. The Australian perspective is particularly informative because Australia was 'philosophically 
situated midway between the East and West' in that, whilst still possessing an inferiority complex with other 'colonial subjects', Australians viewed themselves as 'superior to their Oriental counterparts'. She utilises document analyses, player diaries, personal communications, and interviews to construct a narrative of the tour from the perspective of the players. She notes that, prior to travel, many of the players had encountered very little ethnic diversity in their lives, and their preconceptions of India were informed mainly by populist writings about the exoticism of the Orient as espoused in the writings of Rudyard Kipling. Her analysis shows that whilst in some ways the players demonstrated an atypical cultural sensitivity to the Orient and the 'Other', in others, they were culturally naïve, subscribing to western ideologies depicting the Orient as irrational, dangerous and backward.

Parvathi Raman provides the first of two papers in this special issue examining the role and significance of cricket in the South Asian diaspora. She focuses specifically on the UK context and begins by arguing, 'The story of South Asians and their relationship to cricket in postwar Britain sheds light on the complex politics of belonging in the postcolony, and illustrates that diaspora is ultimately an assemblage of collective association'. Raman's contribution is original in that, whilst the majority of current literature into cricket and South Asians treat diaspora as a 'condition' which is 'transcended, or realised primarily as a form of resistance', her account looks into how South Asianness is nurtured and celebrated through listening to, watching, supporting and playing cricket. She draws upon interviews conducted with South Asian men and women in England and India to develop a picture for how the South Asian diaspora in Britain has appropriated cricket as a defining feature of their postcolonial national identities. She argues that cricket, specifically the spaces it is consumed and played 'bred solidarity through generations, and across communities. They became spaces of diasporic connectivity'. Raman also notes that cricket plays an ambiguous role within the South Asian diaspora in Britain, in that, on the one hand it helps nourish their 'otherness'; on the other hand it helps produce 'homeliness' in the postcolony. She writes, 'The grammar of cricket...nourishes the imaginings of a home 'elsewhere', and makes 'homely' the alien spaces of here and now.'

Thomas Fletcher and Thomas Walle conclude the special issue with their paper 'Negotiating their right to play: Asian-specific cricket teams and leagues in the UK and Norway'. They present a comparative analysis of two separate projects into Pakistani Muslim male cricketers who represent Asian-specific clubs. Their overarching contention, not dissimilar to Raman's, is that through playing cricket diasporic communities are actively engaged in carving out spaces to articulate identity. For Fletcher and Walle, Asian-specific teams and leagues 'act as symbols of community and cultural resistance, facilitate contingent and cultural integration, provide spaces for resisting racism and circumventing the normalisation of 'whiteness'. Their paper centralises Brah's notion of 'diaspora space' on the basis that 'the diaspora space provides diasporic communities with the opportunity(ies) for resisting the processes of exclusion'. According to Fletcher and Walle, playing cricket was integral to the men's self-perception as 'Pakistanis in the world', in that, cricket constituted a social space through which these men could resist and protect themselves from white and antiMuslim racism(s) and Islamaphobia, whilst also celebrating their cultural heritage(s) and traditional activities. Thus, cricket is portrayed as an 'important source of ethnic pride in the men's encounters with others and in their expressions of resistance against processes of marginalisation, Othering, and racism.' 
All of the contributions to this special issue began as presentations at the 'Cricket, migration and diasporic communities around the world' conference, hosted by Leeds Metropolitan University, UK in July, 2012. The conference featured presentations from academics based in the UK, Australia, South Africa, Canada, India and the Caribbean. Topics of presentations were incredibly diverse; both in terms of their content and methodological approach. The papers in this special issue are only able to offer a snapshot of these, but are nevertheless a good reflection of the breadth and depth of current critical scholarship into cricket, race and diaspora at the current time. I would like to thank the contributors for their efforts and hard work in producing what is a though-provoking special issue.

\section{Acknowledgements}

I would like to thank the editorial board at Identities for supporting the idea for this special issue. Thanks in particular to Claire Alexander for taking a 'risk' on such a niche topic. Special thanks must go to Amanda Eastell-Bleakley for getting the special issue to press. Additionally, I would like to express my gratitude to the external reviewers for providing such thoughtful feedback.

\section{References}

Anthias, F., 2001. New hybridities, old concepts: The limits of 'culture'. Ethnic and Racial Studies, 24(4), 619641.

Appadurai, A., 1996. Modernity at large: Cultural dimensions of globalisation. Minneapolis: University of Minnesota Press.

Brah, A., 1996. Cartographies of diaspora: Contesting identities. London: Routledge.

Burdsey, D., Thangaraj, S, and Dudrah, R., 2013. Playing through time and space: Sport and South Asian diasporas. South Asian Popular Culture, 11(3), 211-218.

Cardus, N., 1945. English cricket. London: Collins.

Carrington, B., 2010. Race, sport and politics. London: Sage.

Carrington, B., 2012. Introduction: sport matters. Ethnic and Racial Studies, 35(6), 961-970.

Carrington, B., 2013. The critical sociology of race and sport: The first fifty years. Annual Review of Sociology, 39, 379-398.

Carrington, B. and Andrews, D.L., 2013. Introduction: Sport as escape, struggle and art. In: D.L. Andrews. and B. Carrington, eds. A companion to sport. Chichester, UK; Blackwell.

Crabbe, T. and Wagg, S., 2005. 'A carnival of cricket?' The Cricket World Cup, 'race' and the politics of carnival. In: S. Wagg, ed. Cricket and national identity in the postcolonial age. London: Routledge.

Delgado, R., 2008. Foreword. In: D. Gillborn, ed. Racism and education: Coincidence or conspiracy? London: Routledge.

Fletcher, T., 2012. "Who do 'they' cheer for?" Cricket, diaspora, hybridity and divided loyalties amongst British Asians. International Review for the Sociology of Sport, 47(5), 612-631.

Fletcher, T, and Spracklen, K., 2013. Cricket, Drinking and Exclusion of British Muslims? Ethnic and Racial Studies. DOI: 10.1080/01419870.2013.790983. 
Gemmell, J., 2007. All white mate? Cricket and race in Oz. Sport in Society, 10(1), 33-48.

Gilroy, P., 1993. The black atlantic: Modernity and double consciousness. London: Verso.

Hall, S., 1994. Cultural identity and diaspora. In: P. Williams and L. Chrisman, eds. Colonial discourse and postcolonial theory: A reader. London: Harvester.

Hall, S., 1996. Minimal selves. In: Baker, H.A, Oiwara, M and Lindeborg, R, eds. Black British cultural studies reader. Chicago: University of Chicago Press.

Harkin, F., In Press. The Gaelic Athletic Association and London's 'Irish' diaspora. In: K. Dashper., T. Fletcher. and N. McCullough, eds. Sport events, society and culture. London: Routledge.

James, C.L.R., 2005[1963]. Beyond a boundary. London: Yellow Jersey Press.

Joseph, J., 2012. Culture, community, consciousness: The Caribbean sporting diaspora. International review for the Sociology of Sport. DOI: 10.1177/1012690212465735.

Kalra, V.S., Kaur, R., and Hutnyk, J., 2005. Diaspora and hybridity. London: Thousand Oak.

Khondker, H., 2010. Globalization, cricket and national belonging. In: C. Rumford and S. Wagg, eds, Cricket and globalization. Newcastle-upon-Tyne: Cambridge Scholars.

Malcolm, D., Bairner, A. and Curry, G., 2010. Cricket and cultural difference. In: C. Rumford and S. Wagg, eds, Cricket and globalization. Newcastle-upon-Tyne: Cambridge Scholars.

Malcolm, D., 2013. Globalizing cricket: Englishness, empire and identity. London: Bloomsbury.

Modood, T, and Salt, J., 2013. Global migration, ethnicity and Britishness. Basingstoke: Palgrave Macmillan.

Raman, P., 2003. In search of the 'authentic' diasporic subject. Himal South Asian [online] available from http://www.himalmag.com/component/content/article/4273-in-search-of-the-authentic-diasporicsubject.html [accessed February 11, 2014].

Sandiford, K.A.P., 1998. England. In: B Stoddart and K.A.P. Sandiford, eds. The imperial game: Culture, cricket and society. Manchester: Manchester University Press.

Stephenson, M.L., 2006 Travel and the 'freedom of movement': Racialised encounters and experiences amongst ethnic minority tourists in the EU. Mobilities, 1(2), 285-306.

Williams, J., 2001. Cricket and race. Oxford: Berg.

THOMAS FLETCHER is a Senior Lecturer at Leeds Metropolitan University. ADDRESS: Institute for Sport, Physical Activity and Leisure, Cavendish 114, Leeds Metropolitan University, Leeds, LS6 3QU. 